\title{
Right portal vein thrombosis from idiopathic cause: case report
}

\author{
Trombose da veia porta direita de causa idiopática: relato de caso \\ Trombosis idiopática de la vena porta derecha: informe de caso
}

Received: 01/18/2022 | Reviewed: 01/26/2022 | Accept: 01/27/2022 | Published: 01/28/2022

Júlia Siqueira Fernandes Silveira

ORCID: https://orcid.org/0000-0003-0181-8309

Faculdade Pernambucana de Saúde, Brazil E-mail: julialabmm@gmail.com

Michelle Pereira de Faria e Silva

ORCID: https://orcid.org/0000-0003-3537-3555

Faculdade de Medicina de Olinda, Brazil

E-mail: michelle_pfaria@hotmail.com

Camila Brandão Leal Pereira

ORCID: https://orcid.org/0000-0002-7226-6938

Instituto Metropolitano do Ensino Superior, Brazil

E-mail: camilabrandaolealpereira@gmail.com

Roberta Lara Napoleão Nogueira

ORCID: https://orcid.org/0000-0002-8934-6483

Instituto Metropolitano do Ensino Superior, Brazil

E-mail: roberta.napoleao@hotmail.com

Lays Santana de Freitas

ORCID: https://orcid.org/0000-0003-4316-5860

Faculdade Pernambucana de Saúde, Brazil

E-mail: layssfa@hotmail.com

Lise Reis Melo

ORCID: https://orcid.org/0000-0002-4791-6521

Universidade Federal da Paraíba, Brazil

E-mail: lisereismelo@yahoo.com.br

Joelmir Lucena Veiga da Silva

ORCID: https://orcid.org/0000-0001-5722-0213

Faculdade de Medicina de Olinda, Brazil

E-mail: joelmirluce@hotmail.com

\begin{abstract}
The aim of this study was to describe the case report of a 33-year-old girl with portal vein thrombosis. J.S.D.F., 33 years old, female, previously healthy, with a personal and family history negative for thromboembolic phenomena, without comorbidities, started with severe abdominal pain in the mesogastric region, radiating to HCD and back, associated with vomiting. Smoking active for about 20 years and using OC for 2 years. In view of the symptoms, she sought emergency services, where the first suspicion would be pancreatitis. Initial tests plagued leukocytosis. GUS of the total abdomen with doppler and CT of the abdomen showed the presence of thrombus in the right portal vein, with no other alterations. Rocefin ${ }^{\circledR}$ and metronidazole as an initial measure in the service began in addition to full coagulation with Clexane ${ }^{\circledast}$. It showed clinical and laboratory improvement, with a reduction of leukocytes. The patient remained hospitalized in a hospital for 22 days to investigate the etiological cause. After of hospitalization, the patient was released with medical discharge, with guidelines for seeking the hematology service. During the investigation consultations, the results of the requested tests were negative for the diagnostic suspicions of nocturnal paroxysmal hemoglobinuria and chronic myeloproliferative disease. After 6 months of follow-up, she was discharged from the hematology service because she did not present a suspected disease and classified the cause of thrombolytic event as idiopathic associated with the combined use of OC and smoking.
\end{abstract}

Keywords: Thrombosis; Portal vein; Case report.

\section{Resumo}

O objetivo deste trabalho foi descrever o relato do caso de uma jovem de 33 anos com trombose de veia porta. J.S.D.F., 33 anos, sexo feminino, previamente hígida, com história pessoal e familiar negativas para fenômenos tromboembólicos, sem comorbidades, iniciou quadro com dor abdominal intensa na região mesogástrica, irradiando para HCD e dorso, associado a vômitos. Tabagista ativa há cerca de 20 anos, e em uso de CO há 2 anos. Diante dos sintomas, procurou serviço de emergência, onde a primeira suspeita seria pancreatite. Exames iniciais flagaram leucocitose. USG de abdome total com doppler e TC de abdome evidenciaram presença de trombo na veia porta direita, sem outras alterações. No serviço iniciaram Rocefin ${ }^{\circledR}$ e metronidazol, além da anticoagulação com Clexane ${ }^{\circledR}$. Apresentou melhora clínica e laboratorial, com redução dos leucócitos. Paciente manteve-se internada por 22 dias 
para investigação da causa etiológica. Após o internamento, paciente foi liberada com alta médica, com orientações de procura do serviço de hematologia. Durante as consultas de investigação, os resultados dos exames solicitados apresentaram negativos para as suspeitas diagnósticas de hemoglobinúria paroxística noturna e doença mieloproliferativa crônica. Após 6 meses de acompanhamento, teve alta do serviço de hematologia, por não apresentar doença suspeitada e classificada a causa do evento trombolítico como idiopática associada ao uso combinado de $\mathrm{CO}$ e tabagismo.

Palavras-chave: Trombose; Veia porta; Relato de caso.

\section{Resumen}

El objetivo de este estudio fue describir el caso clínico de una mujer de 33 años con trombosis de la vena porta. J.S.D.F., 33 años, sexo femenino, previamente sana, con antecedentes personales y familiares negativos para fenómenos tromboembólicos, sin comorbilidades, inició con dolor abdominal intenso en región mesogástrica, irradiado a $\mathrm{CDH}$ y espalda, asociado a vómitos. Fumador activo desde hace unos 20 años, y consumidor de CO desde hace 2 años. Ante los síntomas acudió al servicio de urgencias, donde la primera sospecha sería pancreatitis. Las pruebas iniciales mostraron leucocitosis. La ecografía total de abdomen con Doppler y TAC de abdomen mostró la presencia de un trombo en la vena porta derecha, sin otras alteraciones. En el servicio iniciaron Rocefin ${ }^{\circledR}$ y metronidazol, además de anticoagulación con Clexane ${ }^{\circledR}$. Presentó mejoría clínica y de laboratorio, con reducción de leucocitos. El paciente permaneció hospitalizado durante 22 días para investigación de la causa etiológica. Luego del ingreso, el paciente fue dado de alta con alta médica, con lineamientos para buscar el servicio de hematología. Durante las visitas de investigación, los resultados de las pruebas solicitadas fueron negativos para las sospechas diagnósticas de hemoglobinuria paroxística nocturna y enfermedad mieloproliferativa crónica. A los 6 meses de seguimiento, fue dado de alta del servicio de hematología, ya que no tenía sospecha de enfermedad y la causa del evento trombolítico se clasificó como idiopática asociada al uso combinado de ACO y tabaquismo.

Palabras clave: Trombosis; Vena porta; Informe de caso.

\section{Introduction}

Portal vein thrombosis (PVT) is identified by portal venous obstruction caused by a blood clot. Balfour and Stweart (1869) described PVT in first time, being considered the main cause of extrahepatic portal hypertension in patients with normal liver (Belli, et al., 1989). The etiologies of clot formation can be divided into four groups: direct lesion in the portal vein; congenital malformation of the vascular system with involvement of the portal system; indirect factors that influence the formation of the portal vein thrombus; and idiopathic causes (Balfour \& Stewart, 1869).

In the group of acquired etiologies, liver cirrhosis is the most frequent cause in adults, about $25 \%$ of patients with PVT have underlying cirrhosis, while the incidence of PVT in cirrhotic patients is between 0.6 and $17 \%$ (Gonçalves, et al. 2002; Okuda, et al., 1985). In addition, there is mention neoplastic diseases, myeloproliferative diseases, intra-abdominal infectious processes, inflammatory diseases, as COVID-19, complications of medical interventions with manipulation of the portal vein, abdominal trauma, antiphospholipid syndrome, nocturnal paroxysmal hemoglobinuria, in women, pregnancy and the puerperium are highlighted, as well as the use of oral contraceptives or hormone replacement therapy (Muguet, et al., 2022; Mota, et al., 2021; Tavares \& Ortiz, 2021; Alves, et al., 2012). Situations that promote portal vein stasis such as chronic heart failure, constrictive pericarditis and hepatic vein obstruction (Budd-Chiari syndrome) (Merck, 2007) are also associated. Hereditary causes include states of primary hypercoagulability due to antithrombin III deficiency, protein C and Protein S, dysfibrinogenemia, plasminogenemia, the G20201A mutation of the prothrombin gene (Gonçalves, et al., 2002).

Due to the recent diagnosis of more hereditary prothrombotic risk factors and the earlier detection of latent myeloproliferative syndromes, the rate of patients with idiopathic PVT has been reducing (Mahmoud, et al., 1997; Moreira, et al., 2009). Because it is a multifactorial disease, it is admitted that the simultaneous presence of more than one risk factor is necessary for venous thrombosis to occur (Okuda, et al., 1985).

Smoking and prolonged tobacco use (> 20 packs/year), alone, are at increased risk of venous thrombosis compared to nonsmokers, as tobacco is associated with high fibrinogen levels and vascular wall damage by activating the intrinsic coagulation pathway (Rott, 2012). 
The diagnosis is realized, mainly, by ultrasound or computed tomography, although there are safer and more defined ways to establish the diagnosis such as angiography and Doppler abdomen ultrasound (Balfour \& Stewart, 1869; Belli, et al., 1989). Already, digestive endoscopy is indicated to evidence the presence of esochial varicose veins (Balfour \& Stewart, 1869).

In proposal to treatment, thrombolytic therapy with urokinase should be initiated if the thrombus is small, or with heparin. This thrombolytic therapy prevents short-term intestinal ischemia and long-term extrahepatic hypertension (Belli, et al., 1989). If there is no success in thrombolytic therapy, if the patient develops symptomatic, with intestinal ischemia, surgical treatment should be instituted (Balfour \& Stwart, 1869). Therefore, the aim of this study was to report the case of a 33 -year-old girl with portal vein thrombosis.

\section{Methodology}

\subsection{Type of research}

This is a descriptive study, the type of case report (Pereira, et al., 2018).

\subsection{Ethical considerations}

The patient participant signed the Informed Consent Form (TCLE) for the realization and publication of this report. This study was submitted and approved for consideration by the Ethics Committee at School of Medicine of Olinda (CAAE 47974721.2.0000.8033).

\section{Results and Discussion}

J.S.D.F., 33 years old, female, previously healthy, with a personal and family history negative for thromboembolic phenomena, without comorbidities, started with severe abdominal pain in the mesogastric region, radiating to HCD and back, associated with vomiting, without bleeding, mucus or pus. He did not present fever, jaundice, or other associated symptoms. Smoking active for about 20 years, with smoking load of 20 cigarettes/day and using OC (oral contraceptive) for 2 years. In view of the symptoms, she sought emergency services, where the first suspicion would be pancreatitis, because she had already undergone cholecystectomy about 12 years ago. Initial tests plagued leukocytosis of 32,910. GUS of the total abdomen with doppler and CT of the abdomen was requested, which showed the presence of thrombus in the right portal vein, with no other alterations. Rocefin ${ }^{\circledR}$ and metronidazole started in the service as an initial measure in addition to full coagulation with Clexane $^{\circledR}$, a low molecular weight heparin (Natescu, et al., 2016). It showed clinical and laboratory improvement, with a reduction of leukocytes to 19,260 . The patient remained hospitalized in a hospital in the region for 22 days to investigate the etiological cause of the thrombolytic event. The investigation began with follow-up by the hematologist, because it is atypical site thrombosis with associated leukocytosis and thrombosis, it was suggested to rule out nocturnal paroxysmal hemoglobinuria and chronic myeloproliferative disease. Tests were performed to evaluate iron kinetics, Leiden Factor V mutation, homocysteine, JAK-2 gene mutation, BCR-ABL, prothrombin, Protein C and S and MTHFR. In addition to these tests, bone marrow biopsy and flow cytometry were performed for CD55 and CD59 research. It evolved interoccurrences during hospitalization, clinically stable and hemodynamically. With this, after 22 days of hospitalization, the patient was released with medical discharge, with guidelines to seek the hematology service, to continue the etiological investigation and to keep anticoagulation for 6 months with rivaroxaban (Xarelto ${ }^{\circledR}$ ), an oral inhibitor of Factor Xa (Brandão, et al., 2018), and smoking cessation and OC use.

During the investigation consultations, the results of the tests presented negative results for the diagnostic suspicions 
of nocturnal paroxysmal hemoglobinuria and chronic myeloproliferative disease. The patient had hematological follow-up for 6 months, using rivaroxaban medication $\left(\right.$ Xarelto $^{\circledR}$ ). After 6 months of follow-up, she was discharged from the hematology service because she did not present a suspected disease and classified the cause of thrombolytic event as idiopathic associated with the combined use of OC and smoking. Since thrombotic risk is increased in patients with combined alterations (Godoy, et al., 1999) and use of OC contributes to the state of hypercoagulability and development of a thrombotic event (Tzankova, et al., 2010; Junge, et al., 2011; Padovan \& Freitas, 2015; Ortega, et al., 2020; Cruz, et al., 2021).

\section{Final notes}

After etiological investigation, the results of the tests were negative for the diagnostic suspicions of nocturnal paroxysmal hemoglobinuria, coagulopathies and chronic myeloproliferative disease, it was then concluded that the thrombolytic event could be associated with prolonged exposure to AOC and smoking.

In future, additional work will be needed for corroborating in this clinical subject.

\section{References}

Alves, R. L. J., Macedo, F. A., Latorre, M. V., Paula, B. H. R., Barradas, F., \& Tavares, M. (2012). Trombose de veia porta: revisão de literatura e relato de caso. Cadernos UniFOA, 18, 101-108. 10.47385/cadunifoa.v7i18.1096

Balfour, G. W., \& Stewart, T. G. (1869). Case of enlarged spleen complicated with ascites, both depending upon varicose dilatation and thrombosis of the portal vein. Edinburgh Medical Journal, 14(7), 589-598.

Belli, L., Romani, F., Riolo, F., Rondinara G., Aseni, P., Di Stefano, M., Contorni, L., \& Bini, M. (1989). Thrombosis of portal vein in absence of hepatic disease. Surgery, Gynecology \& Obstetrics, 169(1), 46-49.

Brandão, G. M. S, Cândido, R. C. F, Rollo, H. de A., Sobreira, M. L., \& Junqueira, D. R. (2018). Direct oral anticoagulants for treatment of deep vein thrombosis: Overview of systematic reviews. Jornal Vascular Brasileiro, 17(4), 310-317. 10.1590/1677-5449.005518

Cruz, S. L. A. da, Bottega, D. dos S., \& Paiva, M. J. M. de. (2021). Oral contraceptive: side effects and its relationship with venous thrombosis. Research, Society and Development, 10(14), e283101421798. 10.33448/rsd-v10i14.21798

Godoy, J. M. P, Godoy, M. F., Ricci, O., \& Ruiz, M. A. (1999). Hipercoagulabilidade e tromboses. Revista Brasileira de Hematologia e Hemoterapia, 21(3): $127-134$.

Gonçalves, M. L. et al. (2002). Trombose da veia porta e mutação G20210A da protrombina: A Propósito de um Caso Clínico. GE - Jornal Português de Gastrenterologia, 9, 40-44.

Junge, W., Mellinger, U., Parke, S., \& Serrani, M. (2011). Metabolic and haemostatic effects of estradiol valerate/dienogest, a novel oral contraceptive: a randomized, open-label, single-centre study. Clinical Drug Investigation, 31(8), 573-584. 10.2165/11590220-000000000-00000

Mahmoud, A., Elias, E., \& Baeauchamp, N. (1997). Prevalence of the factor V Leiden mutation in hepatic and portal vein thrombosis. Gut, 40(6), 798-800. $10.1136 /$ gut.40.6.798

Merck, M. (2007). Manual Merck de Medicina: diagnóstico e tratamento. (17a ed.), Roca, 2007.

Moreira, A. M., Rabenhorst, S. H. B., Holanda, R. A. R. R., \& Pitombeira, M. H. (2009). Fatores de risco associados a trombose em pacientes do estado do Ceará. Revista Brasileira de Hematologia e Hemoterapia, 31(3), 132-136, 2009. 10.1590/S1516-84842009005000044

Mota, L. P., Sousa, M. V. A. de, Gonçalves, J. N. de A., Leal, N. T. B., Leal, L. B., Negreiros, A. L. B., Silva, D. H. da, Penha, A. A. G. da, Alves, N. S., Ferreira, P. de F., Leal, G. L., Sousa, F. de A. da S., Freitas, F. V. da S., Silveira Filho, E. R. da, Costa, J. D. da, Carvalho, M. M. de, Pereira, M. G. de C., Pereira, S. A., \& Santos, J. M. F. dos. (2021). Development of thrombosis in patients with SARS-CoV-2 infection. Research, Society and Development, 10(9), e52210918246. 10.33448/rsd-v10i9.18246

Muguet, C. M., Guimarães, K., Bastos, L., Baroni, M., Curty, M., Marzano, M., Costa, M., Tardelli, M., Risi, R., Lustosa, R., \& Estato, V. (2022). PostCOVID-19 deep vein thrombosis and its pharmacological management. Research, Society and Development, 11(1), e12311124991. 10.33448/rsd-v11i1.24991

Nutescu E. A., Burnett A., Fanikos, J., Spinler, S., \& Wittkowsky, A. (2016). Pharmacology of anticoagulants used in the treatment of venous thromboembolism. Journal of Thrombosis and Thrombolysis, 41(1), 15-31. 10.1007/s11239-015-1314-3

Okuda, K., Ohnishi, K. \& Kimura, K. (1985). Incidence of portal vein thrombosis in liver cirrhosis: An angiographic study in 708 patients. Gastroenterology, 89(2), 279-286. 10.1016/0016-5085(85)90327-0

Ortega, M. Q., Cruz, R. S., Bernardi, L. G., Braga, M. E. D., \& Dominato, A. A. G. (2020). Thrombotic effects on users of combined oral contraceptives throughout their fertile life: integrative review. Research, Society and Development, 9(11), e77091110458. 10.33448/rsd-v9i11.10458 
Research, Society and Development, v. 11, n. 2, e38311225833, 2022

(CC BY 4.0) | ISSN 2525-3409 | DOI: http://dx.doi.org/10.33448/rsd-v11i2.25833

Padovan, F. T., \& Freitas, G. (2015). Anticoncepcional oral associado ao risco de trombose venosa profunda. Brazilian Journal of Surgery and Clinical Research, 9(1), 73-77.

Pereira, A. S., Shitsuka, D. M., Parreira, F. J. \& Shitsuka, R. (2018). Metodologia da pesquisa cientifica. UFSM.

Rott, H. (2012). Thrombotic risks of oral contraceptives. Current Opinion in Obstetrics and Gynecology, 24(4), 235-240. 10.1097/GCO.0b013e328355871d

Tavares, L. da S., \& Ortiz, J. V. (2021). Development of thrombosis in patients with and without SARS-Cov-2 infection - literature review. Research, Society and Development, 10(15), e410101522959. 10.33448/rsd-v10i15.22959

Tzankova, V, Petrov, V, \& Danchev, N. (2010). Impact of oral contraceptives and smoking on arterial and deep venous thrombosis: a retrospective case-control study. Biotechnology \& Biotechnological Equipment, 24(3), 2026-2030. 10.2478/V10133-010-0054-Y 